\title{
In utero alcohol exposure increases mammary tumorigenesis in
} rats

\author{
L Hilakivi-Clarke ${ }^{*, 1,4}$, A Cabanes ${ }^{1,4}$, S de Assis', M Wang', G Khan', WJ Shoemaker ${ }^{2}$ and RG Stevens ${ }^{3}$ \\ 'Lombardi Cancer Center and Department of Oncology, Georgetown University, 3970 Reservoir Road, NW, Washington, DC 20007, USA; ' Department \\ of Psychiatry, University of Connecticut Health Center, 263 Farmington Avenue, Farmington, CT 06030-6325, USA; ${ }^{3}$ Department of Community \\ Medicine, University of Connecticut Health Center, 263 Farmington Avenue, Farmington, CT 06030-6325, USA
}

Findings in humans and animal models suggest that in utero hormonal and dietary exposures increase later breast cancer risk. Since alcohol intake by adult women consistently increases their breast cancer risk, we wondered whether maternal alcohol consumption during pregnancy increases female offspring's mammary tumorigenesis. In our study, pregnant female rats were pair-fed isocaloric

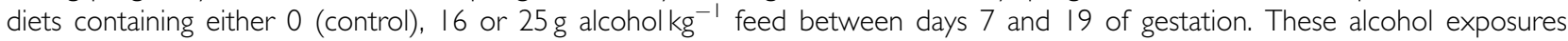
generate blood alcohol levels that correspond to low and moderate alcohol consumption and are lower than those that induce foetal alcohol syndrome. Serum oestradiol levels were elevated in pregnant rats exposed to alcohol $(P<0.003)$. When adult, female offspring of alcohol-exposed dams developed significantly more 7,12-dimethylbenz[a]anthracene -induced mammary tumours, compared to the controls (tumour multiplicity; mean \pm s.e.m., controls: $2.0 \pm 0.3,16 \mathrm{~g}$ alcohol: $2.7 \pm 0.4$ and $25 \mathrm{~g}$ alcohol: $3.7 \pm 0.4$; $P<0.006)$. In addition, the mammary epithelial tree of the alcohol-exposed offspring was denser $(P<0.004)$ and contained more structures that are susceptible for the initiation of breast cancer $(P<0.00 \mathrm{I})$. Immunohistochemical assessment indicated that the mammary glands of 22-week-old in utero alcohol-exposed rats contained elevated levels of oestrogen receptor- $\alpha(P<0.04)$ that is consistent with the changes in mammary gland morphology. In summary, maternal alcohol intake during pregnancy increases female offspring's mammary tumorigenesis, perhaps by programming the foetal mammary gland to exhibit persistent alterations in morphology and gene expression. It remains to be determined whether an increase in pregnancy oestradiol levels mediated alcohol's effects on offspring's mammary tumorigenesis.

British Journal of Cancer (2004) 90, 2225-223I. doi:I0.1038/sj.bjc.660I793 www.bjcancer.com

Published online II May 2004

(c) 2004 Cancer Research UK

Keywords: in utero exposures; alcohol; breast cancer; oestrogen receptor; mammary gland

Some breast cancers may be pre-initiated in utero following an exposure to elevated maternal oestrogen levels that stimulate the growth of foetal mammary gland and might cause long-lasting alterations in the expression of oestrogen-regulated genes (Trichopoulos, 1990; Hilakivi-Clarke et al, 2002). Our goal has been to identify factors that modify pregnancy oestrogen levels and daughter's breast cancer risk. These studies have to be performed first using animal models that mimic human breast cancer, since it is difficult to examine interactions between in utero exposures and breast cancer that is detected several decades later in women.

One factor that might modify pregnancy hormone levels is diet: for example, maternal intake of a high-fat n-6 polyunsaturated fatty acid diet increases both pregnancy oestradiol (E2) levels and carcinogen-induced mammary tumorigenesis among female offspring, mimicking the effects seen when pregnant dams are treated

\footnotetext{
*Correspondence: Dr L Hilakivi-Clarke, Georgetown University, NRB, Lombardi Cancer Center, Research Building, Room W405, 3970 Reservoir Road, NW, Washington, DC 20057-2197, USA;

E-mail: clarkel@georgetown.edu

${ }^{4}$ Both authors contributed equally to the study

Received 28 October 2003; revised 23 February 2004; accepted 24 February 2004; published online II May 2004
}

with E2 (Hilakivi-Clarke et al, 1997b). Another dietary factor that might modify pregnancy E2 levels is alcohol. Alcohol intake increases serum oestrogen levels (Hankinson et al, 1995), possibly by stimulating aromatase activity (Purohit, 2000), and alcohol has been consistently linked to increased risk of developing breast cancer (Smith-Warner et al, 1998; Singletary and Gapstur, 2001; Hamajima et al, 2002). Studies in humans indicate that mothers reporting having consumed some alcohol during pregnancy have higher pregnancy E2 levels than women who do not drink any alcohol during pregnancy (Petridou et al, 1992; Wuu et al, 2002). It is not known, however, whether alcohol exposure in utero through a pregnant mother increases later breast cancer risk (Stevens and Hilakivi-Clarke, 2001).

The aim of our study was to determine whether maternal alcohol exposure increases pregnancy E2 levels and female offspring's risk of developing mammary tumours in rats. In addition, we studied possible changes in the mammary gland morphology and expression of oestrogen receptor (ER)- $\alpha$. These receptors mediate the effects of oestrogens on the breast, through a complex signalling network, and are clearly involved in the mammary gland development (Saji et al, 2000). Findings in vitro indicate that alcohol increases ER- $\alpha$ expression in human breast cancer cells (Fan et al, 2000; Singletary et al, 2001). Further, earlier human studies have shown that high alcohol intake is linked to increased 
mammographic density (Vachon et al, 2000) that in turn is associated with increased breast cancer risk (Boyd et al, 2001). Findings in animal studies also suggest that alcohol modifies mammary gland development (Singletary et al, 1991). The goal of our study was to determine whether alcohol exposure during pregnancy might increase mammary gland ER- $\alpha$ levels, epithelial density and number of epithelial targets for malignant transformation (terminal end buds (TEBs)).

\section{METHODS}

\section{Maternal alcohol exposure}

Pregnant Sprague-Dawley rats were obtained from Charles River on day 7 of gestation. The rats were housed individually in standard rat plexiglas cages, at a constant temperature and humidity, under a 12-h light-dark cycle (lights on $0600 \mathrm{~h}$ ). All the experiments reported in this manuscript were carried out with the appropriate institutional ethical committee approval and they met the standards of both the US federal regulations and those required by the UKCCCR guidelines (Workman et al, 1998).

To examine whether maternal alcohol intake affects pregnancy oestrogen levels and offspring's mammary tumorigenesis, the rats were divided into three groups ( $n=15$ per group) upon arrival on gestation day 7 , and were pair-fed isocaloric liquid diets containing either 0 (control), $16 \mathrm{~g}$ (low, 7\% alcohol of total energy) or $25 \mathrm{~g}$ (moderate, $15 \%$ alcohol of total energy) alcohol kg ${ }^{-1}$ feed (Workman et al, 1998). Other ingredients of the diets were Premix, oil, maltose-dextrin, and deionised water. Diet ingredients were provided by Research Diets, Inc., New Brunswick, N. J. Pre-mix contained the following ingredients (given as $\mathrm{gl}^{-1}$ ): casein (41.4), DL-methionine (0.3), L-cystine (0.5), cellulose (10), xanthan gum (3), complete mineral mix (8.75), complete vitamin mix (2.5) and choline bitartrate (0.53). The oil mix contained corn oil (8.5), olive oil (28.4) and safflower oil (2.7) The control diet also had $115.2 \mathrm{~g}$ of maltodextrin, and the alcohol-containing diets had an amount of maltodextrin removed equivalent to the calories of the added alcohol. Diets were prepared twice a week using a commercial blender.

We did not determine blood alcohol levels (BAL) in this experiment, but were able to estimate them based on previous studies that used identical diets used here (Vavrousek-Jakuba et al, 1991; Catlin et al, 1993; Baker and Shoemaker, 1995). Our estimates were also based on the linearity of BAL following administration of different levels of alcohol. According to these estimates, BAL for the rats receiving the $16 \mathrm{~g}$ alcohol $\mathrm{kg}$ diet is $61.3 \pm 5.0 \mathrm{mg} \mathrm{dl}^{-1}$, and for the $25 \mathrm{~g}$ alcohol $\mathrm{kg}$ diet is $95.8 \pm 6.1 \mathrm{mg} \mathrm{dl}^{-1}$. These BAL are similar to those seen in low-tomodest alcohol drinkers, respectively, and lower than those found to induce foetal alcohol syndrome (FAS) (Singletary and Gapstur, 2001).

Since alcohol intoxication might disrupt normal labour and care of newborn pups, we withdrew pregnant rats from alcohol on gestation day 19. All the animals were fed AIN93 diets from that point onwards.

\section{Effects on pregnancy oestrogen levels}

On gestation day 19 , blood was obtained by cardiac puncture to determine circulating $17 \beta$-oestradiol (E2) levels in dams fed 0 (control), 16 or $25 \mathrm{~g}$ alcohol per $\mathrm{kg}$ feed between gestation days 7 and 19. For that purpose, a specific double antibody kit from ICN Biomedicals, Inc. (Irvine, CA, USA) was used following the manufacturer's instructions. To avoid any cross-reactivity with other serum components, E2 was extracted from serum using a mixture of organic solvents.

\section{Mammary gland morphology}

The mechanisms mediating the effects of in utero exposures on later risk of developing breast cancer could include changes in the mammary gland morphology and expression of genes regulating it. Therefore, wholemounts of the fourth abdominal glands, obtained at different ages and processed as previously described (HilakiviClarke et al, 1997a, b), were assessed for changes in the morphology (Workman et al, 1998). The relative densities of epithelial tree, alveolar buds and lobules were determined in the 8and 22-week-old rats using a five-point visual scale (from: $0=$ absent, to $5=$ numerous) we have previously validated (Hilakivi-Clarke et al, 1997a). The total number of TEBs was counted in 3-, 6-and 8-week-old offspring; that is, at times when their number is at the highest and before they differentiate to lobular-alveolar structures. Identification of each of the epithelial structures was based on the guidelines of mammary gland morphology by Russo and Russo (1987). All the analyses were done double-blinded under an Olympus dissecting microscope.

\section{Oestrogen receptors}

We determined ER- $\alpha$ expression in the mammary glands of 22week-old rats by immunocytochemistry using MC-20 antibody for ER- $\alpha$ (rabbit polyclonal IgG, Santa Cruz Biotechnology, CA, USA) at $1: 100$ dilution. The level of expression was assessed in three ductal and three lobular structures per section. Oestrogen receptor $\alpha$ protein levels were quantitated by using a $0-5$ scale $(\mathrm{O}=$ lowest and $5=$ highest $)$ to determine the percentile of cells showing nuclear staining, and a $0-3$ scale to determine the staining intensity. The average scores for percentile cells stained and staining intensity were added together separately in lobules and ducts.

We also investigated the validity of our quantification method. This was done by determining ER- $\alpha$ levels in 8-week-old nontreated rats that were randomly divided to three groups ( $n=5$ each). If significant differences were found among the groups that should be similar (all nontreated animals), this would suggest that our approach did not reliably predict the true differences between the control and experimental mammary glands.

\section{Effects on offspring's mammary tumorigenesis}

Mammary tumours were induced by administration of $10 \mathrm{mg}$ ( $\sim 50 \mathrm{mg} \mathrm{kg}^{-1}$ body weight) 7,12-dimethylbenz(a)anthracene (DMBA) (Sigma, St Louis, MO, USA) to 47-day-old female rats ( $n=23-25$ per group) (Workman et al, 1998). The histopathology, oestrogen dependence, oestrogen and progesterone receptor expression and antioestrogen responsiveness of the DMBAinduced tumours closely reflect human breast cancer (Russo and Russo, 1987). More than $75 \%$ of the tumours induced by $10 \mathrm{mg}$ DMBA are adenocarcinomas (Russo and Russo, 1996); in our previous experiments, the proportion of adenocarcinomas in the DMBA control group was $80-100 \%$ (Hilakivi-Clarke et al, 2000). The carcinogen was dissolved in peanut oil and administered by oral gavage in a volume of $1 \mathrm{ml}$.

The animals were examined for mammary tumours by palpation once per week. The end points for data analysis were: (i) latency to tumour appearance, (ii) the number of animals with tumours (tumour incidence), (iii) the number of tumours per animal (tumour multiplicity) and (iv) tumour growth rate. During the follow-up, those animals in which tumour burden approximated $10 \%$ of total body weight were killed, as required by our institution. All surviving animals, including those that did not appear to develop mammary tumours, were killed 17 weeks after carcinogen administration. 


\section{Statistical analyses}

Results for the data obtained on: (i) pregnancy-related parameters (pregnancy weight gain, birth weight, number of pups per litter and pregnancy serum E2 levels); (ii) mammary gland morphology (total number of TEBs and density of epithelial tree, ABs and lobules in the whole mounts), (iii) ER- $\alpha$ protein levels and (iv) some mammary tumour end points (latency and multiplicity) were analysed using one- or two-way analysis of variance (ANOVA). When determining latency, only the week when the first tumour was detected was assessed. Animals that did not develop tumours were included in the analysis and given a latency value of the length of follow-up plus one week (18 weeks). When assessing tumour multiplicity, animals that did not develop any tumours were given a value 0 . Where appropriate, between-group comparisons were done using Fisher's least significant difference (LDS) test. Differences in the tumour incidence on week 17 were determined using a $\chi^{2}$ test. The time to tumour presentation was measured as the number of weeks from DMBA exposure to the time the first tumour per animal could be palpated. Estimations of tumour presentation were calculated by the methods developed by Kaplan and Meier (1958). Differences among the treatment arms were tested using an extension of the log rank test and both Gehan's and Peto's generalised Wilcoxon tests as implemented in STATISTICA (Stat soft, 1998). The differences were considered significant if the $P$-value was less than 0.05 . All probabilities are two-tailed.

\section{RESULTS}

\section{Effects on pregnancy outcome and pregnancy E2 levels}

Maternal alcohol exposure did not affect the litter size, birth weight or postnatal weight gain (data not shown). Vaginal opening of the female pups, reflecting puberty onset, was not either affected by in utero alcohol exposures (data not shown).

The E2 levels were significantly higher in the pregnant dams consuming $16 \mathrm{~g}$ alcohol than in the controls $(P<0.05$; $\mathrm{F}(2,27)=7.3, P<0.003$ ) (Figure 1). The difference between the controls and moderate-alcohol-exposed group (25 $\mathrm{g}$ alcohol per $\mathrm{kg}$ feed) did not reach statistical significance.

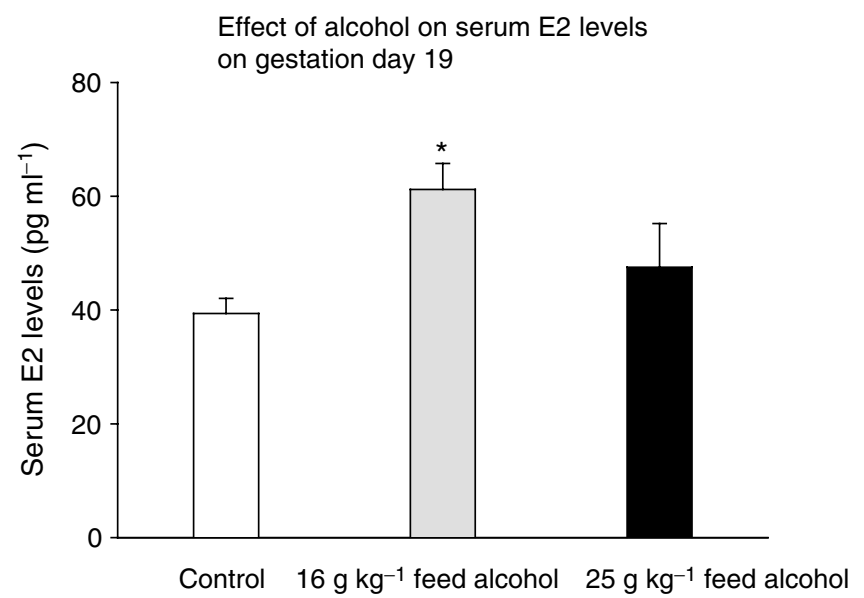

Figure I Circulating oestradiol (E2) levels on gestation day 19 in rats fed $0 \mathrm{~g}$ (control), $16 \mathrm{~g}$ or $25 \mathrm{~g}$ alcohol $\mathrm{kg}^{-1}$ feed between gestation days 7 and 19. The E2 levels were significantly higher in the animals consuming $16 \mathrm{~g}$ alcohol than in the controls, $* P<0.05$.

\section{Effects on offspring's mammary tumorigenesis}

Tumour multiplicity (the total number of palpable tumours per animal) was significantly higher in the rats exposed in utero to alcohol than in the controls $(\mathrm{F}(2,69)=5.53, P<0.006)$ (Figure $2 \mathrm{~A}$ and B). Post hoc analysis revealed that the increase was significant between the control and moderate-alcohol groups. The tumour incidence in all groups approached $100 \%$ and, therefore, no differences in this end point among in utero alcohol-exposed and control rats were seen. However, the incidence was consistently higher in the alcohol groups than controls during each of the 17 weeks of tumour growth monitoring (Figure 2c).

Latency to the appearance of the first tumour was longer in the control group, though not significantly so (mean \pm s.e.m. weeks, control: $9.7 \pm 0.6,16 \mathrm{~g}$ alcohol: $8.4 \pm 0.5,25 \mathrm{~g}$ alcohol: $8.6 \pm 0.5$ ). Latency to any subsequent tumours (control: $10.5 \pm 0.4,16 \mathrm{~g}$ alcohol: $9.7 \pm 0.3,25 \mathrm{~g}$ alcohol: $10.2 \pm 0.3$ ) was not significantly different among the groups. Further, tumour growth rates were similar in all the three groups (data not shown).
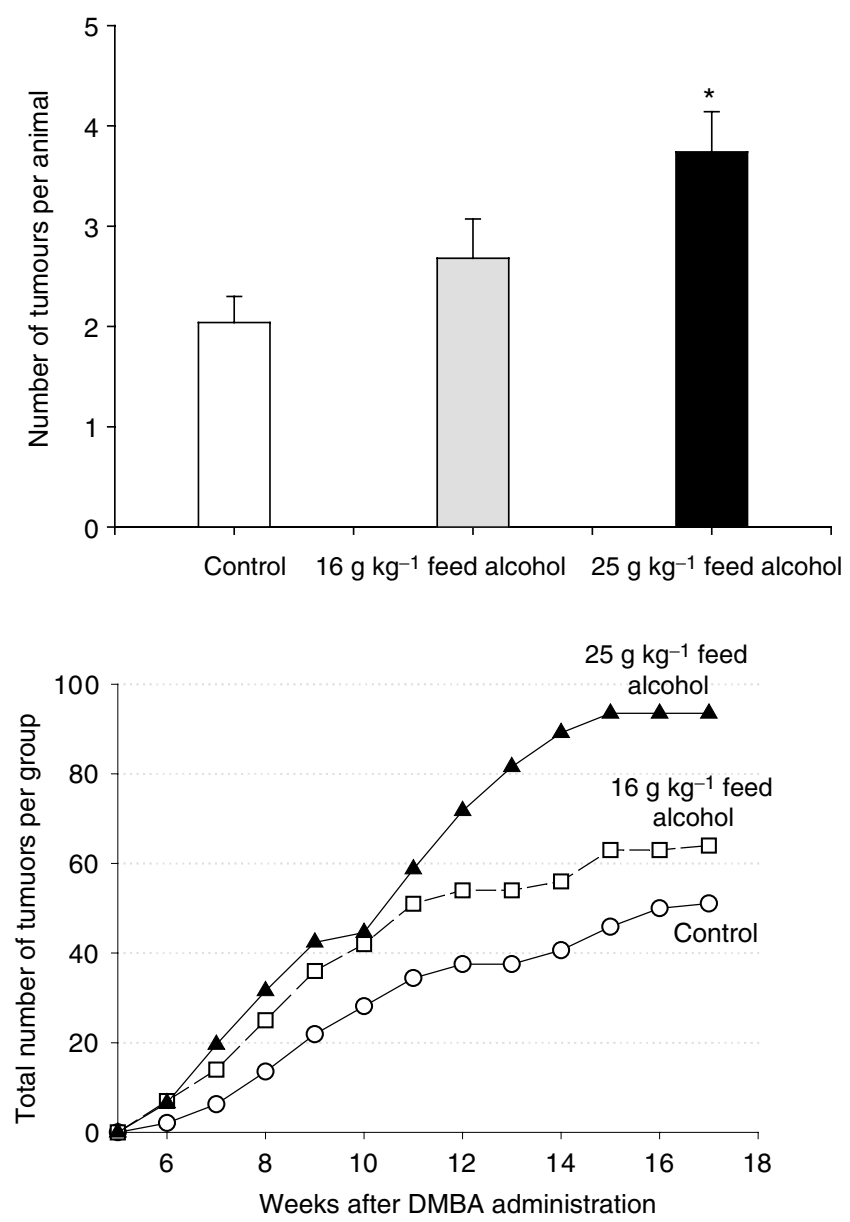

Figure 2 Mammary tumour multiplicity (number of tumours per animal at sacrifice) and total number of tumours per week in rats exposed in utero to $0 \mathrm{~g}$ (control, $n=24), 16 \mathrm{~g}(n=25)$ or $25 \mathrm{~g}(n=23)$ alcohol $\mathrm{kg}^{-1}$ feed, following an exposure to $10 \mathrm{mg} 7,12$-dimethylbenz(a)anthracene (DMBA) on postnatal day 47. The data shown for total number of tumours are standardised to 24 animals per group, using the formula: $24 \times$ total number of tumours per week, divided by the number of animals per group. These latter data are shown to illustrate the differences among groups, and thus were not subjected to statistical analysis. Tumour multiplicity was increased in the $25 \mathrm{~g} \mathrm{~kg}^{-1}$ feed alcohol-exposed rats, compared to the controls: $* P<0.05$. 


\section{Mammary gland morphology}

In utero exposure to alcohol increased epithelial density $(\mathrm{F}(2,24)=7.21, \quad P<0.004)$ and the density of alveolar buds $(\mathrm{F}(2,24)=8.88, P<0.001)$, determined in 8 - and 22 -week-old rats (Figures $3 \mathrm{a}$ and $\mathrm{b}$ ). No changes were noted in the density of lobules (data not shown). The total number of TEBs, assessed in wholemounts of 3-, 6- and 8-week-old rats, was dose-dependently increased during weeks 6 and $8 \quad(\mathrm{~F}(2,39)=12.6, \quad P<0.001)$
(Figure 3c). Representative wholemounts of the fourth abdominal gland in 22-week-old offspring of dams exposed to control, low $\left(16 \mathrm{~g} \mathrm{~kg}^{-1}\right.$ feed) and moderate $\left(25 \mathrm{~g} \mathrm{~kg}^{-1}\right.$ feed $)$ alcohol during pregnancy are also shown (Figure $3 \mathrm{~d}$ ). Our findings indicate that in utero alcohol exposure increases mammary epithelial density and the number of targets for malignant transformation.

Oestrogen receptor- $\alpha$ The validation study that determined ER- $\alpha$ expression using immunohistochemistry in the mammary glands
A

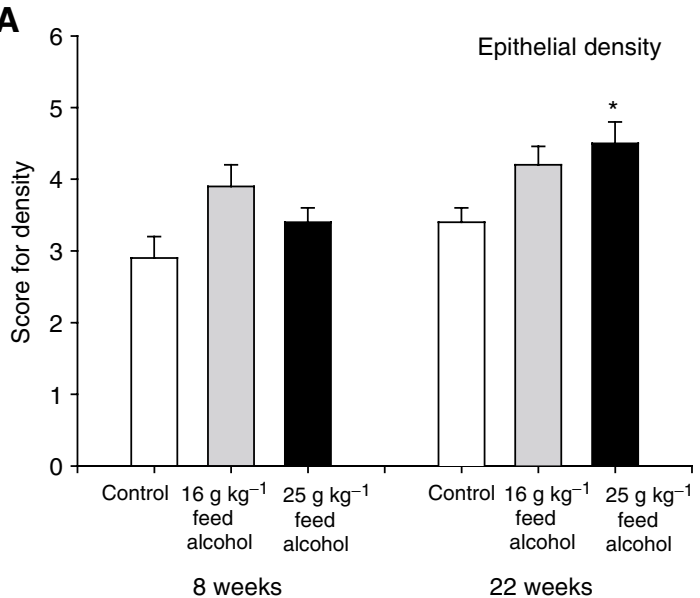

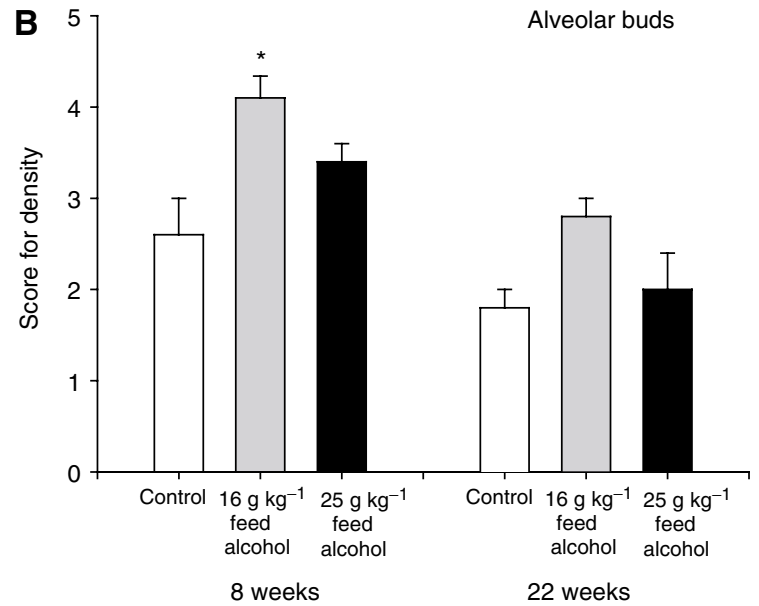

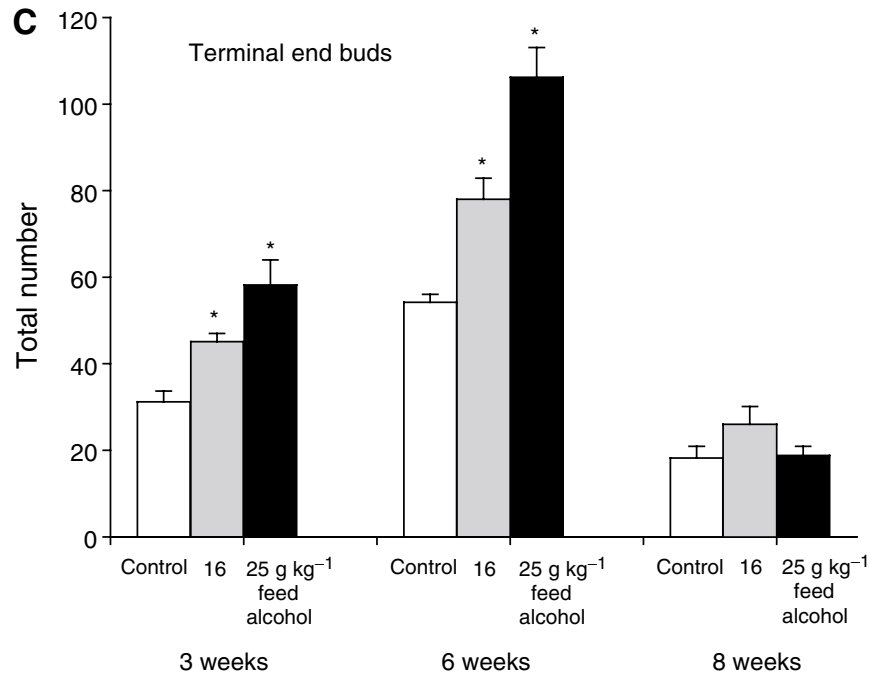

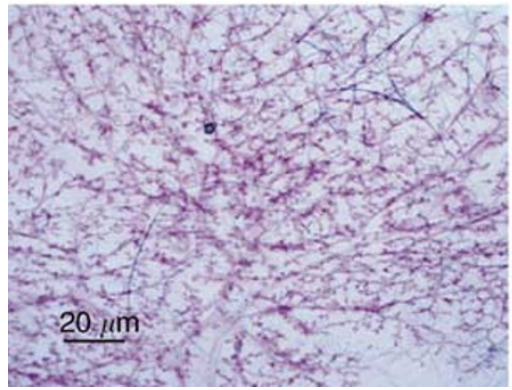

Control

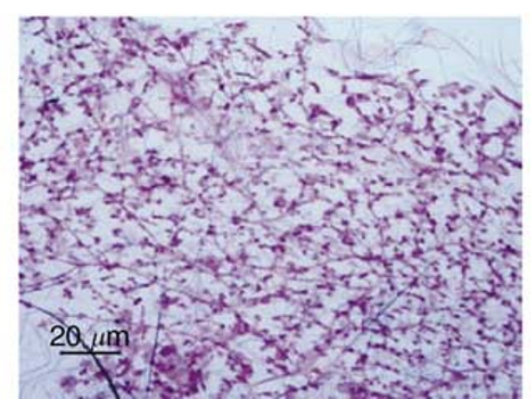

$16 \mathrm{~g} \mathrm{~kg}^{-1}$ feed alcohol

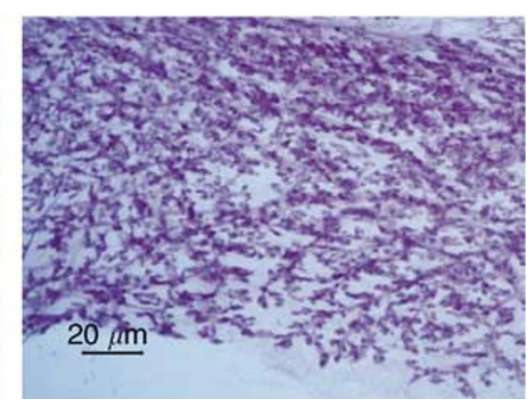

$25 \mathrm{~g} \mathrm{~kg}^{-1}$ feed alcohol

Figure 3 In utero exposure to $0 \mathrm{~g}$ (control), $16 \mathrm{~g}$ or $25 \mathrm{~g}$ alcohol $\mathrm{kg}^{-1}$ feed increase in (A) epithelial density and (B) the density of alveolar buds, determined in 8- and 22-week-old rats. No changes were noted in the density of lobules. The total number of (C) TEBs, assessed in wholemounts of 3-, 6and 8 -week-old rats, was also dose-dependently increased. Statistically different from the controls: $* P<0.05$. Representative wholemounts of the fourth abdominal gland in 22-week-old offspring are shown. 
of three similar groups of nontreated animals showed no differences in either the lobular or ductal ER- $\alpha$ expression among the groups. The proportion of cells stained and staining intensity in the nontreated animals in three lobular and three ductal structures per gland were evaluated using scales of $0-5$ and $0-3$, respectively. The combined scores in the lobules of the three nontreated groups were $3.3 \pm 0.2,3.4 \pm 0.2$ and $3.8 \pm 0.2$, and in the ducts $3.7 \pm 0.3,3.2 \pm 0.3$ and $3.2 \pm 0.2$. These results suggest that our quantitative approach for immunohistochemical assays is unlikely to yield false-positive results.

We then determined ER- $\alpha$ expression in the mammary glands of 22-week-old rats exposed in utero to 0,16 or $25 \mathrm{~g}^{\text {alcohol kg}}{ }^{-1}$ feed. The results showed that the levels of ER- $\alpha$ protein were elevated in the mammary gland of the rats exposed to alcohol in utero (ER- $\alpha$ $(\mathrm{F}(2,18)=3.9, P<0.04)$ (Figures $4 \mathrm{a}$ and $\mathrm{b}$ ). These changes were dose-dependent and significant only in the offspring of dams consuming $25 \mathrm{~g}_{\text {alcohol kg}}^{-1}$ feed-containing diets during pregnancy, when compared to the controls.

\section{DISCUSSION}

Many dietary factors are suggested to be linked to either increased or reduced breast cancer risk, but the data supporting these associations are mostly contradictory. Alcohol consumption is an exception, and there is a consensus that alcohol intake increases the risk of developing breast cancer (Smith-Warner et al, 1998; Singletary and Gapstur, 2001; Hamajima et al, 2002). Some epidemiological studies suggest that alcohol drinking during adolescence and early adulthood has the strongest impact on breast cancer risk (Harvey et al, 1987; Hiatt et al, 1988; Young, 1989; Garland et al, 1999), while results of some studies indicate that drinking later in life increases breast cancer risk most (Longnecker et al, 1995; Swanson et al, 1997). Data obtained in the present study suggest that alcohol exposure already in utero through a pregnant mother may increase breast cancer risk.
The idea that some breast cancers are pre-initiated in utero is supported by several indirect observations in human populations. These studies show that women who were exposed to high foetal oestrogenic environment; that is, had a high birth weight or are twins, are at an increased risk of developing breast cancer (Braun et al, 1995; Michels et al, 1996; Sanderson et al, 1996; Weiss et al, 1997). At a particularly high risk are twins whose birth weight was high (Hubinette et al, 2001). A recent study also found that women exposed to the synthetic oestrogen diethylstilbestrol (DES) in utero are at an increased risk of developing breast cancer (Palmer et al, 2002). Animal studies support the hypothesis. In rats, maternal exposure to either oestradiol or DES increases the offspring's breast cancer risk (Walker, 1984; Hilakivi-Clarke et al, 1997b).

We found that maternal exposure to relatively low alcohol levels increased pregnancy E2 levels in rats. Previous human studies have shown that both acute and chronic alcohol consumption increases circulating E2 levels in non-pregnant women (Hankinson et al, 1995), possibly by alcohol-induced increase in aromatase activity (Purohit, 2000). A positive association between alcohol intake during pregnancy and pregnancy oestrogen levels in humans has also been reported (Petridou et al, 1992; Wuu et al, 2002). Thus, the present data in animals and earlier data in humans show that maternal alcohol consumption increases pregnancy E2 levels. However, since the dams kept on the highest alcohol diet did not show a significant increase in pregnancy E2 levels, although this group showed most differences in tumorigenesis, it remains to be determined whether the increased oestrogenicity in alcoholexposed pregnant dams explains their offspring's increased mammary tumorigenesis.

The mechanisms mediating the effect of in utero alcohol exposure on mammary tumorigenesis may be linked to changes in mammary gland morphology and gene expression. Oestrogens stimulate normal mammary epithelial and tumour cell proliferation (Nandi et al, 1995), also when administered neonatally (Hilakivi-Clarke et al, 1997a, b). In vitro and in vivo studies show that alcohol increases normal and malignant mammary cell
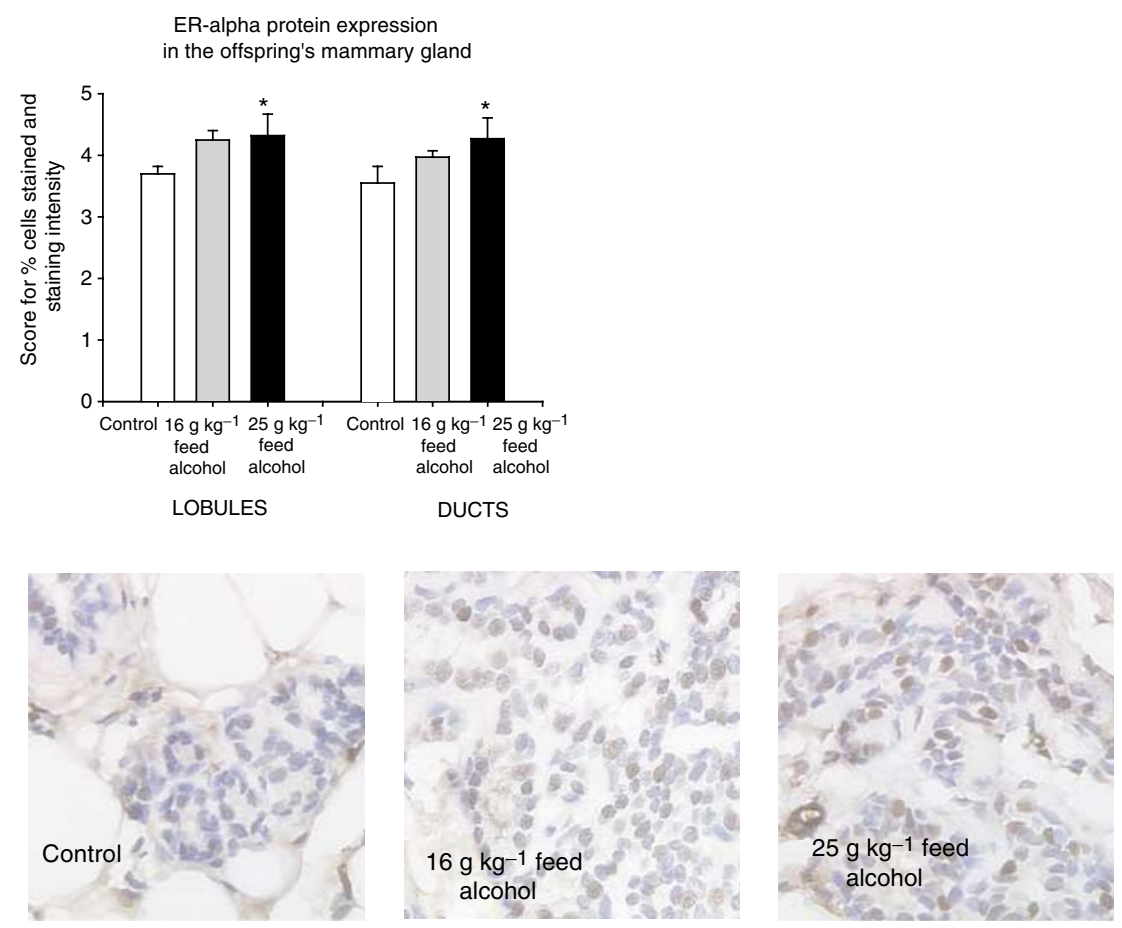

Figure 4 In utero exposure to $0 \mathrm{~g}$ (control), $16 \mathrm{~g}$ or $25 \mathrm{~g}$ alcohol $\mathrm{kg}^{-1}$ feed increased oestrogen receptor (ER)- $\alpha$ levels in the mammary glands of 22 -weekold rats. Statistically different from the controls: $* P<0.05$. Representative sections of each of the three treatment groups for ER- $\alpha$ staining are shown. 
proliferation (Singletary et al, 2001). In humans, alcohol is associated with increased mammographic density (Vachon et al, 2000), and increased density is linked to four- to six-fold increase in breast cancer risk (Boyd et al, 2001). These findings suggest that elevated oestrogen levels in utero may have led to increased mammary epithelial density seen in rats exposed to alcohol in utero, and the increased density in turn increased the risk of developing mammary tumours.

Earlier studies have reported that rats exposed to diets containing $15-20 \%$ of energy from alcohol as juveniles exhibit an increased number of TEBs and reduced lobular and alveolar bud structures in their mammary glands (Singletary et al, 1991). We found that rats exposed to alcohol in utero had an increased number of TEBs, suggesting that alcohol exposure during foetal life modifies the pathways controlling development of the mammary gland. Further, since TEBs are targets for malignant transformation (Russo and Russo, 1987), their increased presence could explain why alcohol increases mammary tumorigenesis.

In addition to affecting mammary gland morphology, in utero alcohol exposure was found to increase the expression of ER- $\alpha$ in the mammary gland, consistent with earlier in vitro data (Fan et al, 2000; Singletary et al, 2001) and data showing that the level of alcohol intake correlates with ER- $\alpha$ expression in human breast tumours (Enger et al, 1999). Activation of ER- $\alpha$ induces proliferation of normal and malignant breast cells, and is associated with promotion of breast cancer (Tonetti and Jordan, 1999). If ER- $\alpha$ is important in mediating the effects of in utero alcohol exposure in increasing breast cancer risk, its levels should be elevated in women who develop breast cancer. This assumption is supported by findings showing that normal cells in the breasts containing a tumour express higher levels of ER- $\alpha$ than the cells in the breast containing a benign lesion (Khan et al, 1998). Further, breast ER- $\alpha$ levels are significantly lower in the Asian women exhibiting a low breast cancer risk than in the Caucasian women exhibiting a high breast cancer risk (Lawson et al, 1999).

Findings obtained in this study showing that maternal alcohol intake increased offspring's mammary tumorigenesis suggest that the role of maternal diet in modifying pregnancy oestrogen levels and affecting daughter's breast cancer risk should be investigated further. Since oestrogen levels vary by four- to six-fold among women undergoing normal pregnancy, and the reasons for the variability remain poorly understood, it is essential to identify dietary factors that modify pregnancy oestrogen levels and could therefore potentially affect daughter's breast cancer risk. Alcohol might be one of these factors. It has been known for some time that maternal alcohol consumption during pregnancy can cause FAS or its less severe manifestation, foetal alcohol effects in the offspring. The fact that maternal alcohol intake at levels that are considerable lower than those inducing FAS might also increase daughter's breast cancer risk gives further weight to the recommendation that women should avoid consuming alcohol during pregnancy.

\section{ACKNOWLEDGEMENTS}

We thank Aaron Foxhall for performing the animal studies, and Johan Clarke and Antonia Chezek for technical assistance. The study was supported by grants received from the Susan G Komen Breast Cancer Foundation and Breast Cancer Research Foundation (to L H-C).

\section{REFERENCES}

Baker RA, Shoemaker WJ (1995) Effect of prenatal ethanol and stress on levels of beta-endorphin in different brain regions of the rat. Alcohol Clin Exp Res 19: $727-734$

Boyd NF, Martin LJ, Stone J, Greenberg C, Minkin S, Yaffe MJ (2001) Mammographic densities as a marker of human breast cancer risk and their use in chemoprevention. Curr Oncol Rep 3: 314-321

Braun MM, Ahlbom A, Floderus B, Brinton LA, Hoover RN (1995) Effect of twinship on incidence of cancer of the testis, breast, and other sites (Sweden). Cancer Causes Control 6: 519-524

Catlin MC, Abdollah S, Brien JF (1993) Dose-dependent effects of prenatal ethanol exposure in the guinea pig. Alcohol 10: 109-115

Enger SM, Ross RK, Paganini-Hill A, Longnecker MP, Bernstein L (1999) Alcohol consumption and breast cancer oestrogen and progesterone receptor status. $\mathrm{Br} J$ Cancer 79: 1114-1308

Fan S, Meng Q, Gao B, Grossman J, Yadegari M, Goldberg ID, Rosen EM (2000) Alcohol stimulates estrogen receptor signaling in human breast cancer cell lines. Cancer Res 60: 5635-5659

Garland M, Hunter DJ, Colditz GA, Spiegelman DL, Manson JE, Stampfer MJ, Willett WC (1999) Alcohol consumption in relation to breast cancer risk in a cohort of United States women 25-42 years of age. Cancer Epidemiol Biomarkers Prev 8: 1017-1121

Hamajima N, Hirose K, Tajima K, Rohan T, Calle EE, Heath Jr CW, Coates RJ, Liff JM, Talamini R, Chantarakul N, Koetsawang S, Rachawat D, Morabia A, Schuman L, Stewart W, Szklo M, Bain C, Schofield F, Siskind V, Band P, Coldman AJ, Gallagher RP, Hislop TG, Yang P, Kolonel LM, Nomura AM, Hu J, Johnson KC, Mao Y, De Sanjose S, Lee N, Marchbanks P, Ory HW, Peterson HB, Wilson HG, Wingo PA, Ebeling K, Kunde D, Nishan P, Hopper JL, Colditz G, Gajalanski V, Martin N, Pardthaisong T, Silpisornkosol S, Theetranont C, Boosiri B, Chutivongse S, Jimakorn P, Virutamasen P, Wongsrichanalai C, Ewertz M, Adami HO, Bergkvist L, Magnusson C, Persson I, Chang-Claude J, Paul C, Skegg DC, Spears GF, Boyle P, Evstifeeva T, Daling JR, Hutchinson WB, Malone K, Noonan EA, Stanford JL, Thomas DB, Weiss NS, White E, Andrieu N, Bremond A, Clavel F, Gairard B, Lansac J, Piana L, Renaud R, Izquierdo A, Viladiu P, Cuevas HR, Ontiveros P, Palet A, Salazar SB, Aristizabel N,
Cuadros A, Tryggvadottir L, Tulinius H, Bachelot A, Le MG, Peto J, Franceschi S, Lubin F, Modan B, Ron E, Wax Y, Friedman GD, Hiatt RA, Levi F, Bishop T, Kosmelj K, Primic-Zakelj M, Ravnihar B, Stare J, Beeson WL, Fraser G, Bullbrook RD, Cuzick J, Duffy SW, Fentiman IS Hayward JL, Wang DY, McMichael AJ, McPherson K, Hanson RL, Leske MC, Mahoney MC, Nasca PC, Varma AO, Weinstein AL, Moller TR, Olsson H, Ranstam J, Goldbohm RA, van den Brandt PA, Apelo RA, Baens J, de la Cruz JR, Javier B, Lacaya LB, Ngelangel CA, La Vecchia C, Negri E, Marubini E, Ferraroni M, Gerber M, Richardson S, Segala C, Gatei D, Kenya P, Kungu A, Mati JG, Brinton LA, Hoover R, Schairer C, Spirtas R, Lee HP, Rookus MA, van Leeuwen FE, Schoenberg JA, McCredie M, Gammon MD, Clarke EA, Jones L, Neil A, Vessey M, Yeates D, Appleby P, Banks E, Beral V, Bull D, Crossley B, Goodill A, Green J, Hermon C, Key T, Langston N, Lewis C, Reeves G, Collins R, Doll R, Peto R, Mabuchi K, Preston D, Hannaford P, Kay C, Rosero-Bixby L, Gao YT, Jin F, Yuan JM, Wei HY, Yun T, Zhiheng C, Berry G, Cooper Booth J, Jelihovsky T, MacLennan R, Shearman R, Wang QS, Baines CJ, Miller AB, Wall C, Lund E, Stalsberg H, Shu XO, Zheng W, Katsouyanni K, Trichopoulou A, Trichopoulos D, Dabancens A, Martinez L, Molina R, Salas O, Alexander FE, Anderson K, Folsom AR, Hulka BS, Bernstein L, Enger S, Haile RW, Paganini-Hill A, Pike MC, Ross RK, Ursin G, Yu MC, Longnecker MP, Newcomb P, Bergkvist L, Kalache A, Farley TM, Holck $S$, Meirik O. Collaborative Group on Hormonal Factors in Breast Cancer. Alcohol, tobacco and breast cancer - collaborative reanalysis of individual data from 53 epidemiological studies, including 58515 women with breast cancer and 95067 women without the disease. $\mathrm{Br} J$ Cancer (2002); 87: 1234-1245

Hankinson SE, Willett WC, Manson JE, Hunter DJ, Colditz GA, Stampfer MJ, Longcope C, Speizer FE (1995) Alcohol, height, and adiposity in relation to estrogen and prolactin levels in postmenopausal women. J Natl Cancer Inst 87: 1297-1302

Harvey EB, Schairer C, Brinton LA, Hoover RN, Fraumeni Jr JF (1987) Alcohol consumption and breast cancer. J Natl Cancer Inst 78: 657-661 Hiatt RA, Klatsky AL, Armstrong MA (1988) Alcohol consumption and the risk of breast cancer in a prepaid health plan. Cancer Res 48: $2227-2284$ 
Hilakivi-Clarke L, Cabanes A, Olivo S, Kerr L, Bouker KB, Clarke R (2002) Do estrogens always increase breast cancer risk? J Steroid Biochem Mol Biol 80: $163-174$

Hilakivi-Clarke L, Cho E, Onojafe I, Liao DJ, Clarke R (2000) Maternal exposure to tamoxifen during pregnancy increases carcinogen-induced mammary tumorigenesis among female rat offspring. Clin Cancer Res 6: $305-338$

Hilakivi-Clarke L, Cho E, Raygada M, Kenney N (1997a) Alterations in mammary gland development following neonatal exposure to estradiol, transforming growth factor alpha, and estrogen receptor antagonist ICI 182,780. J Cell Physiol 170: 279-289

Hilakivi-Clarke L, Clarke R, Onojafe I, Raygada M, Cho E, Lippman ME (1997b) A maternal diet high in $n-6$ polyunsaturated fats alters mammary gland development, puberty onset, and breast cancer risk among female rat offspring. Proc Natl Acad Sci USA 94: $9372-9397$

Hubinette A, Lichtenstein P, Ekbom A, Cnattingius S (2001) Birth characteristics and breast cancer risk: a study among like-sexed twins. Int J Cancer 91: 248-251

Kaplan EL, Meier P (1958) Nonparametric estimation form incomplete observations. I Am Stat Assoc 53: 457 - 481

Khan SA, Rogers MA, Khurana KK, Meguid MM, Numann PJ (1998) Estrogen receptor expression in benign breast epithelium and breast cancer risk. J Natl Cancer Inst 90: 37-342

Lawson JS, Field AS, Champion S, Tran D, Ishikura H, Trichopoulos D (1999) Low oestrogen receptor alpha expression in normal breast tissue underlies low breast cancer incidence in Japan. Lancet 354: $1718-1787$

Longnecker MP, Newcomb PA, Mittendorf R, Greenberg ER, Clapp RW, Bodgan GF, Baron J, McMahon B, Willett WC (1995) Risk of breast cancer in relation to lifetime alcohol consumption. J Natl Cancer Inst 87: 923-999

Michels KB, Trichopoulos D, Robins JM, Rosner BA, Manson JE, Hunter D, Colditz GA, Hankinson SE, Speizer FE, Willett WC (1996) Birthweight as a risk factor for breast cancer. Lancet 348: 1516-1542

Nandi S, Guzman RC, Yang J (1995) Hormones and mammary carcinogenesis in mice, rats, and humans: a unifying hypothesis. Proc Natl Acad Sci USA 92: 3637 - 3650

Palmer JR, Hatch EE, Rosenberg CL, Hartge P, Kaufman RH, Titus-Ernstoff L, Noller KL, Herbst AL, Rao RS, Troisi R, Colton T, Hoover RN (2002) Risk of breast cancer in women exposed to diethylstilbestrol in utero: preliminary results (United States). Cancer Causes Control 13: $753-778$

Petridou E, Katsouyanni K, Spanos E, Skalkidis Y, Panagiotopoulou K, Trichopoulos D (1992) Pregnancy estrogens in relation to coffee and alcohol intake. Ann Epidemiol 2: $227-241$

Purohit V (2000) Can alcohol promote aromatization of androgens to estrogens? A review. Alcohol 22: $117-123$

Russo IH, Russo J (1996) Mammary gland neoplasia in long-term rodent studies. Environ Health Perspect 104: 938-967

Russo J, Russo IH (1987) Biological and molecular bases of mammary carcinogenesis. Lab Invest 57: $112-137$

Saji S, Jensen EV, Nilsson S, Rylander T, Warner M, Gustafsson JA (2000) Estrogen receptors alpha and beta in the rodent mammary gland. Proc Natl Acad Sci USA 97: 337 - 342
Sanderson M, Williams M, Malone KE, Stanford JL, Emanuel I, White E, Daling JR (1996) Perinatal factors and risk of breast cancer. Epidemiology 7: $34-37$

Singletary KW, Frey RS, Yan W (2001) Effect of ethanol on proliferation and estrogen receptor-alpha expression in human breast cancer cells. Cancer Lett 165: 117-131

Singletary KW, Gapstur SM (2001) Alcohol and breast cancer: review of epidemiologic and experimental evidence and potential mechanisms. JAMA 286: $2143-2251$

Singletary KW, McNary MQ, Odoms AM, Nelshoppen J, Wallig MA (1991) Ethanol consumption and DMBA-induced mammary carcinogenesis in rats. Nutr Cancer 16: 13-123

Smith-Warner SA, Spiegelman D, Yaun SS, van den Brandt PA, Folsom AR, Goldbohm RA, Graham S, Holmberg L, Howe GR, Marshall JR, Miller AB, Potter JD, Speizer FE, Willett WC, Wolk A, Hunter DJ (1998) Alcohol and breast cancer in women: a pooled analysis of cohort studies. JAMA 279: $535-540$

Stat soft I (1998) STATISTICA for Windows. Computer Program Manual. Tulsa: StatSoft Inc

Stevens RG, Hilakivi-Clarke L (2001) Alcohol exposure in utero and breast cancer risk later in life. Alcohol Alcohol 36: 227-276

Swanson CA, Coates RJ, Malone KE, Gammon MD, Schoenberg JB, Brogan DJ, McAdams M, Potischman N, Hoover RN, Brinton LA (1997) Alcohol consumption and breast cancer risk among women under age 45 years. Epidemiology 8: $227-231$

Tonetti DA, Jordan VC (1999) The estrogen receptor: a logical target for the prevention of breast cancer with antiestrogens. J Mamm Gland Biol Neoplasia 4: $401-413$

Trichopoulos D (1990) Hypothesis: does breast cancer originate in utero? Lancet 355: $939-940$

Vachon CM, Kuni CC, Anderson K, Anderson VE, Sellers TA (2000) Association of mammographically defined percent breast density with epidemiologic risk factors for breast cancer (United States). Cancer Causes Control 11: 653-662

Vavrousek-Jakuba EM, Baker RA, Shoemaker WJ (1991) Effect of ethanol on maternal and offspring characteristics: comparison of three liquid diet formulations fed during gestation. Alcohol Clin Exp Res 15: 129-135

Walker BE (1984) Tumors of female offspring of mice exposed prenatally to diethylstilbestrol. I Natl Cancer Inst 73: $133-140$

Weiss HA, Potischman N, Brinton LA, Brogan D, Coates RJ, Gammon MD, Malone KE, Schoenberg JB (1997) Prenatal and perinatal risk factors for breast cancer in young women. Epidemiology 8: 117-181

Workman P, Twentyman P, Balkwill F, Balmain A, Chaplin D, Double J, Embleton J, Newell D, Raymond R, Stables J, Stephens T, Wallace J (1998) United Kingdom Co-ordinating Committee on Cancer Research (UKCCCR) guidelines for the welfare of animals in experimental neoplasia (second edition). Br J Cancer 77: $1-10$

Wuu J, Hellerstein S, Lipworth L, Wide L, Xu B, Yu GP, Kuper H, Lagiou P, Hankinson SE, Ekbom A, Carlstrom K, Trichopoulos D, Adami HO, Hsieh CC (2002) Correlates of pregnancy oestrogen, progesterone and sex hormone-binding globulin in the USA and China. Eur J Cancer Prev 11: $283-293$

Young TB (1989) A case-control study of breast cancer and alcohol consumption habits. Cancer 64: $552-558$ 